\title{
PENINGKATAN KEMAMPUAN MOTORIK KASAR ANAK USIA 3 - 4 TAHUN MELALUI PERMAINAN ENGKLEK DI POS PAUD TERPADU MADANI SURABAYA
}

\author{
Rodiyah \\ Pos Paud Terpadu Madani, Surabaya \\ Bundarodiyah1@gmail.com
}

\begin{abstract}
ABSTRAK
Penelitian ini bertujuan untuk memperbaiki proses dan hasil pembelajaran sebagai upaya meningkatkan kemampuan motorik kasar anak usia 3 - 4 tahun di PPT Madani Surabaya. Jenis penelitian ini adalah penelitian tindakan kelas yang dilakukan dalam II siklus, subjek dalam penelitian ini adalah anak didik usia 3 - 4 Tahun di PPT Madani Surabaya tahun ajaran 2018/2019. Berjumlah 15 anak yang terdiri dari 11 laki-laki dan 4 perempuan. Pengumpulan data dilakukan melalui unjuk kerja, Observasi dan dokumentasi. Teknik analisis data di lakukan dengan menggunakan statistik deskriptif sederhana, data di analisis secara kuantitatif dan kualitatif. Hasil penelitian ini menujukan bawa keterampilan motorik kasar anak usia dini dapat ditingkatkan melalui permainan tradisional engklek. Peningkatan kemampuan motorik kasar anak secara keseluruhan sebelum adanya tindakan meningkat dari $44.4 \%$ dengan kategori kurang baik, menjadi $77.7 \%$ dengan kategori cukup pada siklus I, menjadi 93.3\% dengan kategori baik pada siklus II.
\end{abstract}

Kata Kunci : Pendidikan Anak Usia Dini, Motorik Kasar, Permainan Engklek

\begin{abstract}
This study aims to improve the process and outcomes of learning as an effort to improve gross motor skills on Early Childhood at PPT Madani Surabaya. This research is a classroom action research conducted in the third cycle, the subjects in this study is a on Early Childhood PPT Madani Suabay academic year 2018/2019. The 15 Early Childhood consisting of 11 men and 4 women. Data collected through the performance, observation and documentation. Data analysis techniques done by using simple descriptive statistics, the data were analyzed quantitatively and qualitatively. The results of this study bring addressing the gross motor skills of early childhood can be enhanced through the traditional hopscotch game. The increase in gross motor skills of Early Childhood in its entirety before any action to increase from $44.4 \%$ with unfavorable category, to $55 \%$ with the category enough in the first cycle, being $93.3 \%$ with both categories at the second cycle.
\end{abstract}

Keyword: Early Childhood, Gross Motor Skill, Engklek Traditional Games 


\section{PENDAHULUAN}

Anak usia dini merupakan masa pertumbuhan seorang anak dengan rasa ingin tahu yang sangat tinggi. Menurut Wong (2009:45) "Pertumbuhan merupakan perubahan kuantitatif yaitu peningkatan jumlah dan ukuran sel yang akan menghasilkan peningkatan ukuran dan berat seluruh atau sebagian bagian sel sedangkan perkembangan merupakan perubahan kualitatif yaitu perubahan fungsi tubuh yang terjadi secara bertahap dari tingkat yang paling rendah ke tingkat yang paling tinggi melalui proses kematangan dan belajar. Pertumbuhan dan perkembangan mempunyai arti yang berbeda, Pertumbuhan akan berdampak terhadap aspek fisik sedangkan perkembangan berkaitan dengan pematangan fungsi organ dan individu. Kedua kondisi tersebut saling berkaitan dan berpengaruh pada tumbuh kembang pada setiap anak". esesuaian aspek perkembangan anak secara fisik dan mental yang dapat dilihat pada Permendikbud Nomer 137 tahun 2014 tentang standar tingkat pencapaian perkembangan anak usia dini atau disebut juga STPPA,

Tabel 1

Standar Isi Tentang Tingkat Pencapaian Perkembangan Anak

\begin{tabular}{|c|c|}
\hline $\begin{array}{c}\text { Lingkup } \\
\text { Perkembangan }\end{array}$ & Tingkat Pencapaian Perkembangan Anak \\
\hline Motorik Kasar & $\begin{array}{l}\text { 1. Berlari sambil membawa sesuatu yang ringan (bola) } \\
\text { 2. Naik-turun Tangga atau tempat yang lebih tinggi } \\
\text { dengan kaki bergantian } \\
\text { 3. } \\
\text { 4eniti diatas papan yang cukup lebar } \\
\text { Melompat turun dari ketinggian kurang lebih } 20 \mathrm{~cm} \\
\text { 5. } \\
\text { Meniru gerakan senam sederhana seperti menirukan } \\
\text { gerakan pohon, kelinci melompat } \\
\text { 6. } \\
\text { Berdiri dengan satu kaki }\end{array}$ \\
\hline
\end{tabular}

Aspek yang perlu diperhatikan oleh orangtua dan pendidik ada 6 yaitu: nilai agama dan moral, fisik motorik, kognitif, Bahasa, sosial emosional, dan seni. Melalui bermain, semua aspek perkembangan anak dapat ditingkatkan. Bermain merupakan pendekatan dalam mengelola kegiatan belajar anak, dengan menerapkan metode, strategi, sarana, dan media belajar yang merangsang anak untuk melakukan eksplorasi, menemukan dan menggunakan benda-benda yang ada di sekitarnya. Menurut Semiawan (2002:16) "bermain bagi anak adalah kegiatan yang serius tetapi menyenangkan, bermain adalah 
aktivitas yang dipilih sendiri oleh anak karena menyenangkan, bukan karena hadiah atau pujian. Pada penelitian ini peneliti fokus pada "peningkatan motorik kasar pada anak usia 3-4 tahun di PPT Madani Surabaya”. Hal ini di dasarkan pada pengamatan awal yang penulis lakukan dimana hasil menunjukkan bahwa dari 15 anak usia 3-4 tahun di PPT Madani saat guru memberikan tugas untuk menirukan gerakan binatang, melompat, berdiri satu kaki saat melakukan senam, melempar benda ke satu titik, pemanfaatan media pembelajaran luar kelas saat istirahat seperti papan titian, perosotan, dan ayunan anak-anak belum menunjukkan kemampuan motorik kasarnya secara optimal. Motorik Kasar adalah gerak anggota badan secara kasar atau keras. Suyadi dalam E.Berk (2010:68), berpendapat semakin anak bertambah dewasa dan kuat tubuhnya, maka gaya geraknya semakin sempurna. Toho dan Gusril (2004:51), Fungsi motorik adalah mengembangkan kesanggupan dan keterampilan setiap individu yang berguna untuk mempertinggi daya kerja. Iswinarti ( 2010:5 ) menyebutkan bahwa salah satu permainan tradisional yang dapat diterapkan untuk menigkatkan motorik kasar adalah engklek. Dhamamulyo ( 2005:145 ) menjelaskan bahwa "permainan engklek atau ingkling dinamakan demikian karena dilakukan dengan melakukan engklek,yaitu berjalan berlompat dengan satu kaki. dengan perkembangan Intelektual, sosial, emosi dan kepribadian anak. Iswinarti (2007:6) juga menemukan beberapa variasi nama engklek di beberapa daerah di Indonesia antara lain: Engklek (Jawa), Intingan (Sampit), Tengge-tengge (Gorontalo), Cak Lingking (Bangka), Dengkleng (Bali), Bendang (Lumajang), Tepok Gunung (Jawa Barat), sonda (Mojokerto), Gili-gili (merauke) dan lainnya. Pada penelitian ini akan anak usia 3-4 tahun di PPT Madani akan diperkenalkan dengan bentuk engklek kapal-kapalan.

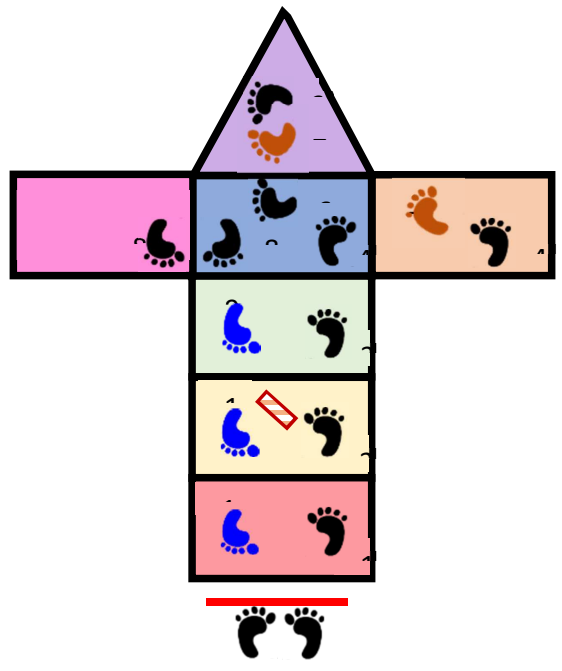

\section{Keterangan:}

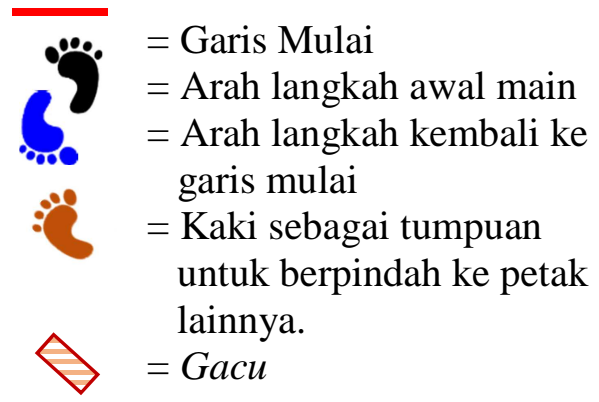




\section{Gambar 1. Aturan Permainan Engklek}

Permainan engklek ini sangat bermanfaat untuk mengembangkan pengendalian gerakan tubuh. Melalui permainan engklek juga berguna untuk memupuk pertemanan dalam aspek sosial emosional dan dapat meningkatkan kemampuan fisiknya, serta dapat mengekspresikan kreativitasnya.

\section{METODOLOGI}

Jenis penelitian yang sesuai dengan penelitian ini adalah penelitian tindakan kelas (PTK). Kesesuaian jenis penelitian ini karena akan dilakukan secara kolaboratif yaitu adanya kerjasama antara guru dan peneliti terhadap siswa di kelas. Suharsimi Arikunto, dkk ( 2012: 17) berpendapat bahwa, tindakan yang dilakukan pada penelitian ini akan diberikan oleh guru atau dengan arahan dari guru yang dilakukan oleh siswa. Pada penelitian ini subjek yang diteliti adalah 15 anak usia dini di PPT Madani Surabaya dengan rentang usia 3 sampai 4 tahun. Dengan obyek penelitian peningkatan kemampuan motorik kasar terhadap subyek anak usia 3 sampai 4 tahun di PPT Madani Surabaya. Prosedur pelaksanaan penelitian yakni ada 2 tahapan: Pra Tindakan dan penelitian tindakan kelas (PTK). model penelitian Kemmis dan Robin McTaggart. ini berupa uraian-uraian dengan satu perangkat terdiri dari empat komponen yaitu perencanaan (planning), tindakan (action), pengamatan (observe) dan refleksi (reflection). Pelaksanaan tindakan dalam penelitian tindakan kelas ini dilaksanakan oleh guru sesuai RPPH \& RPPM (Rencana Pelaksanaan Pembelajaran Harian \& Mingguan) yang telah disusun. Tindakan penelitian yang dilaksanakan yakni : Kegiatan awal (30 menit), Kegiatan Inti (60 menit) dan Kegiatan Penutup (30 menit). Pengumpulan data dalam hal ini menggunakan teknik pengamatan dan dokumentasi, pengamatan dalam bentuk Checklist $(\sqrt{ })$, dengan 4 kolom skala penilaian: berkembang sangat baik (BSB), berkembang sesuai harapan (BSH), mulai berkembang (MB), belum berkembang (BB). Dengan instrument pengumpelan data yakni lembar pengamatan.Teknik analisis data pada penelitian ini adalah Deskriptif Kualitatif dan Kuantitatif. Melalui teknik pengamatan ini dapat diperoleh data dari hasil catatan lapangan yang terdapat pada lembar pengamatan dan dokumentasi foto yang dikumpulkan dari tes awal hingga tes akhir.

$$
P=\frac{F}{n} x 100 \%
$$


$\underline{\text { Keterangan : }}$

$P=$ Angka Persentase (\%)

$F=$ Frekuensi siswa yang mendapatkan treatment

$n=$ Jumlah keseluruhan anak.

\section{HASIL DAN PEMBAHASAN}

\section{Hasil Tahap Pra Tindakan}

Kondisi awal sebelum tindakan menunjukan bahwa keterampilan motorik kasar anak terbilang rendah. Pada penelitian ini untuk mengetahui keterampilan motorik kasar anak dilakukan pengamatan awal saat pembelajaran berlangsung. Pada tahap pra tindakan, pertama guru memberi contoh gerakan senam sederhana yaitu berdiri satu kaki, melompati petak dan melempar gacu untuk menunjukan bahwa keterampilan motorik kasar anak yang nyata berdasarkan kemampuan memperhatikan dan mengingat gerakangerakan yang di contohkan oleh guru di depan. terlihat pada kriteria (Berdiri Seimbang) Anak dengan kategori Berkembang dengan baik 0 anak atau (0\%) berkembang sesuai harapan 2 anak atau (13\%), mulai berkembang ada 7 anak atau (47\%) dan dalam kategori belum berkembang ada 6 anak atau (40\%). Dalam kriteria (Melompat Seimbang) terdapat 0 anak atau $(0 \%)$ kategori berkembang sangat baik dalam melintasi karpet busa, kemudian kategori berkembang sesuai harapan ada 3 anak atau (20\%), mulai berkembang ada 5 anak atau (33\%) dan katergori belum berkembang ada 7 anak atau (47\%). Dalam Kriteria (Melempar ) Ada 1 anak atau (7\%) yang menunjukkan perkembangan yang sangat baik dalam melempar benda, 2 anak atau (13\%) yang masuk kategori berkembang sesuai harapan, mulai berkembang 8 anak atau (53\%) dan 4 anak (27\%) masih belum berkembang.

Berdasarkan hasil pengamatan awal yang dilakukan diperoleh data sebagai berikut:

Tabel 1.

Hasil pengamatan tahap Pra tindakan

\begin{tabular}{|c|c|c|c|c|c|c|c|}
\hline \multirow{2}{*}{ No } & \multirow{2}{*}{ Nama } & $\begin{array}{c}\text { Berdiri } \\
\text { Seimbang }\end{array}$ & $\begin{array}{c}\text { Melompat } \\
\text { Seimbang }\end{array}$ & Melempar & Nilai & Rata" & $\%$ \\
\hline 1 & Rakai & 2 & 1 & 2 & 5 & 1.667 & 41.67 \\
\hline 2 & Daffa & 2 & 1 & 3 & 6 & 2 & 50 \\
\hline 3 & Bhanu & 3 & 1 & 1 & 5 & 1.667 & 41.67 \\
\hline 4 & Arsha & 3 & 3 & 1 & 7 & 2.333 & 58.33 \\
\hline 5 & Ganesha & 2 & 2 & 1 & 5 & 1.667 & 41.67 \\
\hline 6 & Isco & 2 & 3 & 3 & 8 & 2.667 & 66.67 \\
\hline
\end{tabular}




\begin{tabular}{|c|c|c|c|c|c|c|c|}
7 & Rayhan & 2 & 3 & 4 & 9 & 3 & 75 \\
\hline 8 & Yusuf & 1 & 1 & 1 & 3 & 1 & 25 \\
\hline 9 & Febri & 1 & 1 & 1 & 3 & 1 & 25 \\
\hline 10 & Alvino & 2 & 2 & 3 & 7 & 2.333 & 58.33 \\
\hline 11 & Albi & 1 & 1 & 1 & 3 & 1 & 25 \\
\hline 12 & Rino & 1 & 2 & 3 & 6 & 2 & 50 \\
\hline 13 & Edra & 1 & 2 & 1 & 4 & 1.333 & 33.33 \\
\hline 14 & Raisha & 2 & 2 & 1 & 5 & 1.667 & 41.67 \\
\hline 15 & Felisha & 1 & 1 & 2 & 4 & 1.333 & 33.33 \\
\hline & & 26 & 26 & 28 & 80 & 26.67 & 44.44 \\
\hline
\end{tabular}

\section{Keterangan:}

Nilai 1 : Belum Berkembang (BB)

Nilai 2 : Mulai Berkembang (MB)

Nilai 3 : Berkembang Sesuai Harapan (BSH)

Nilai 4 : Berkembang Sangat Baik (BSB)

$P=\frac{F}{n} \times 100 \%$ yang menunjukkan hasil, $P=\frac{80}{15} \times 100 \%=53,3$

Berdasarkan penjabaran tabel diatas, peningkatan kemampuan motoric kasar anak usia 3-4 tahun di PPT Madani Surabaya masih kurang.

\section{Tahap Siklus I Pertemuan 1}

Pada tahap perencanaan siklus I tanggal 7 Maret 2019, Peneliti melakukan pengenalan kegiatan sesuai Rencana Pelaksanaan Pembelajaran Harian dan mingguan yang bekerjasama dengan guru kelas untuk penulis dapat menyesuaikan materi pembelajaran di PPT Madani Surabaya. Pada Siklus I Pertemuan I Pada siklus I pertemuan 1 keterampilan motorik kasar anak masih belum mengalami banyak perubahan dari tahap pra tindakan. Namun pada tahap ini anak sudah mendapatkan gambaran tentang permainan engklek, aturan dan cara bermain engklek.

\section{Tahap Siklus I Pertemuan 2}

Hasil penelitian siklus 1 pertemuan ke 2 ini hasilnya akan di refleksikan guna menentukan apakah penelitian pada siklus 1 cukup sebagai hasil akhir penelitian atau perlu adanya penelitian lanjut ke siklus 2 . 
Tabel 2.

Hasil Pengamatan Siklus I Pertemuan 2 Kemampuan Motorik Kasar anak usia 3-4 Tahun di PPT Madani Surabaya

\begin{tabular}{|c|c|c|c|c|c|c|c|}
\hline \multirow{2}{*}{ No } & \multirow{2}{*}{ Nama } & \multicolumn{3}{|c|}{ Siklus I Pertemuan 2} & \multirow{2}{*}{ Nilai } & \multirow{2}{*}{ Rata" } & \multirow{2}{*}{$\%$} \\
\cline { 3 - 5 } & & $\begin{array}{c}\text { Berdiri } \\
\text { seimbang }\end{array}$ & $\begin{array}{c}\text { Melompat } \\
\text { seimbang }\end{array}$ & Melempar & & & \\
\hline 1 & Rakai & 3 & 3 & 3 & 9 & 3 & 75 \\
\hline 2 & Daffa & 4 & 2 & 3 & 9 & 3 & 75 \\
\hline 3 & Bhanu & 4 & 4 & 3 & 11 & 3.667 & 91.67 \\
\hline 4 & Arsha & 3 & 4 & 4 & 11 & 3.667 & 91.67 \\
\hline 5 & Ganesha & 3 & 3 & 3 & 9 & 3 & 75 \\
\hline 6 & Isco & 3 & 3 & 4 & 10 & 3.333 & 83.33 \\
\hline 7 & Rayhan & 4 & 4 & 3 & 11 & 3.667 & 91.67 \\
\hline 8 & Yusuf & 2 & 3 & 4 & 9 & 3 & 75 \\
\hline 9 & Febri & 2 & 3 & 1 & 6 & 2 & 50 \\
\hline 10 & Alvino & 3 & 1 & 4 & 8 & 2.667 & 66.67 \\
\hline 11 & Albi & 4 & 4 & 3 & 11 & 3.667 & 91.67 \\
\hline 12 & Rino & 2 & 3 & 4 & 9 & 3 & 75 \\
\hline 13 & Edra & 3 & 4 & 2 & 9 & 3 & 75 \\
\hline 14 & Raisha & 3 & 4 & 2 & 9 & 3 & 75 \\
\hline 15 & Felisha & 3 & 3 & 3 & 9 & 3 & 75 \\
\hline & & 46 & 48 & 46 & 140 & 46.7 & 77.78 \\
\hline
\end{tabular}

$P=\frac{F}{n} x 100 \%$ yang menunjukkan hasil, $P=\frac{140}{15} x 100 \%=93,3$

Artinya dari nilai sempurna 12 di kali kan jumlah keseluruhan siswa yaitu 180 , didapatkan nilai 140 pada siklus I pertemuan 2 sehingga nilai persentase kelas yang didapatkan $93,3 \%$.

\section{Tahap Siklus II Pertemuan 1}

Pada Siklus II Pertemuan I atau pertama ini menindak lanjuti hasil dari refleksi siklus I yang hasilnya belum sesuai harapan penulis, sehingga pada siklus II anak yang berhasil melakukan gerakan permainan engklek dengan baik dan memperhatikan akan diberikan stiker bintang sebagai reward untuk anak agar semakin bersemangat saat bermain. 


\section{Tahap Siklus II Pertemuan 2}

Pada Siklus II Pertemuan II Keterampilan motorik kasar anak mulai terlatih dalam bermain permainan engklek, data peningkatan pada siklus II Pertemuan 2 ini sudah sesuai dengan indicator keberhasilan yang diharapkan peneliti sehingga tidak perlu melanjutkan ke tahap lain. Berikut data siklus II:

Tabel 3.

Hasil Pengamatan Siklus II Pertemuan 2 Kemampuan Motorik Kasar anak usia 3-4 Tahun di PPT Madani Surabaya

\begin{tabular}{|c|c|c|c|c|c|c|c|}
\hline \multirow{2}{*}{ No } & \multirow{2}{*}{ Nama } & \multicolumn{3}{|c|}{ Siklus II Pertemuan2 } & \multirow{2}{*}{ Nilai } & Rata" & Berdiri \\
\cline { 3 - 5 } & & $\begin{array}{c}\text { Melompat } \\
\text { Seimbang }\end{array}$ & Melempar & & & \\
\hline 1 & Rakai & 4 & 4 & 4 & 12 & 4 & 100 \\
\hline 2 & Daffa & 4 & 3 & 4 & 11 & 3.667 & 91.67 \\
\hline 3 & Bhanu & 4 & 4 & 4 & 12 & 4 & 100 \\
\hline 4 & Arsha & 4 & 4 & 4 & 12 & 4 & 100 \\
\hline 5 & Ganesha & 4 & 4 & 4 & 12 & 4 & 100 \\
\hline 6 & Isco & 4 & 4 & 4 & 12 & 4 & 100 \\
\hline 7 & Rayhan & 4 & 4 & 4 & 12 & 4 & 100 \\
\hline 8 & Yusuf & 2 & 3 & 4 & 9 & 3 & 75 \\
\hline 9 & Febri & 4 & 4 & 2 & 10 & 3.333 & 83.33 \\
\hline 10 & Alvino & 4 & 2 & 4 & 10 & 3.333 & 83.33 \\
\hline 11 & Albi & 4 & 4 & 4 & 12 & 4 & 100 \\
\hline 12 & Rino & 3 & 4 & 4 & 11 & 3.667 & 91.67 \\
\hline 13 & Edra & 4 & 4 & 3 & 11 & 3.667 & 91.67 \\
\hline 14 & Raisha & 4 & 4 & 2 & 10 & 3.333 & 83.33 \\
\hline 15 & Felisha & 4 & 4 & 4 & 12 & 4 & 100 \\
\hline & & 57 & 56 & 55 & 168 & 56 & 93.33 \\
\hline
\end{tabular}

Hasil penelitian pada tahap siklus II ini menghasilkan data pengamatan:

$P=\frac{F}{n} \times 100 \%$ yang menunjukkan hasil, $P=\frac{168}{15} x 100 \%=112$

Dari penilaian siswa yang bermain engklek dengan kategori berkembang dengan sangat baik, ada 8 anak, 3 anak yang berkembang sesuai harapan, dan 4 anak lainnyamulai berkembang. Pada tahap pra tindakan persentase rata-rata peningkatan kemampuan anak masih belum terlihat yakni nilai total 80 dengan rata-rata nilai 26,7 dan persentase $44,4 \%$. Kemudian dilanjutkan ke Siklus I Pertemuan 1 memperoleh nilai total 99 dengan rata-rata 33 dan persentase 
$55 \%$, Siklus I Pertemuan 2 sedikit meningkat nilai total menjadi 140 dengan rata-rata 46,7 dan persentase $77,78 \%$. Tahap tersebut belum memenuhi Indikator keberhasilan yang diharapkan oleh penulis seperti tujuan awal, penulis melanjut kan ke Siklus II Pertemuan 1 kembali meningkat nilai total yang diperoleh 150 dengan rata-rata 50 dan persentase $83,3 \%$, dilanjutkan kembali ke Siklus II Pertemuan 2 dengan nilai total 168 dan rata-rata 56 serta persentase 93,3\%. Karena siklus II sudah cukup memenuhi indikator pencapaian yang diharapkan, maka penulis melanjutkan ke tahap akhir yaitu Siklus II untuk mengetahui perubahan yang terjadi setelah melalui treatment permainan engklek yang diberikan dan membandingkannya dengan pra tindakan di awal penelitian. Maka dapat ditarik kesimpulan bahwa motorik kasar anak usia 3-4 tahun dapat dikembangkan melalui permainan engklek di PPT Madani Surabaya dapat dibuktikan dengan data antara pra tindakan dan Siklus II yaitu rentang perbandingan nilai sebesar 88 dengan persentase $48,8 \%$. Adapun grafik dari data tersebut:

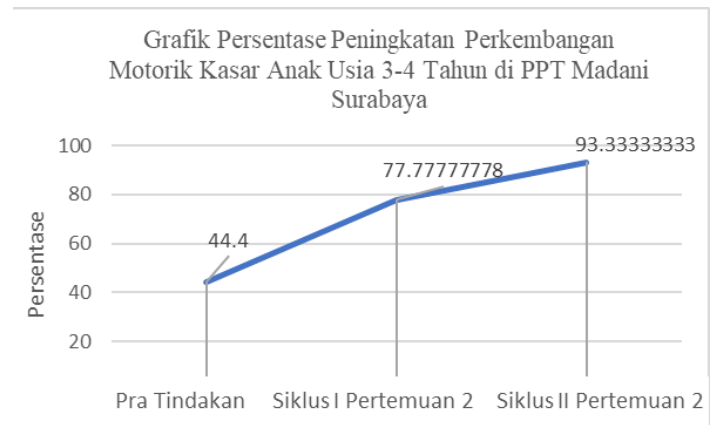

Gambar 2. Grafik peningkatan pada tahap pra tindakan, siklus I dan siklus II

\section{PENUTUP}

\section{Kesimpulan}

Permainan engklek merupakan pembelajaran baru di PPT Madani Surabaya dan belum pernah diberikan. Setelah diberi stimulasi permainan engklek selama lima kali pertemuan, satu kali pertemuan pra tindakan, dua kali pertemuan tahap siklus I dan dua kali pertemuan siklus II anak mencapai indikator keberhasilan yang diharapkan peneliti dan observer. Pada penelitian siklus II pertemuan 2 dengan nilai total 168 dan rata-rata 56 serta dapat dilihat kemampuan motorik kasar anak meningkat sebanyak 14 dari 15 anak masuk dalam kategori berkembang sangat baik dengan persentase 93,3\%. Karena siklus II tersebut sudah memenuhi indikator pencapaian perkembangan 
motorik kasar anak melalui permainan engklek yang diharapkan, kemudian membandingkan perubahan yang terjadi setelah melalui treatment permainan engklek pada pra tindakan di awal penelitian dan akhir di tahap siklus II Pertemuan 2.

Maka dapat ditarik kesimpulan bahwa motorik kasar anak usia 3-4 tahun dapat dikembangkan melalui permainan engklek di PPT Madani Surabaya.

\section{DAFTAR PUSTAKA}

Arikunto., S. 2006. Metode Penelitian Kualitatif. Jakarta: Bumi Aksara

Dharmamulya., Sukirman, dkk. 2005. Permainan Tradisional Jawa. Yogyakarta: Kepel Press.

Gunarti., Winda dkk, 2008, Metode Pengembangan Perilaku dan Kemampuan Dasar Anak Usia Dini, Jakarta: Universitas Terbuka.

Hurlock, Elizabeth B. 1978. Perkembangan Anak Jilid 1. Terjemahan dari Bahasa Inggris oleh Tjandrasa dan Zarkasih. Jakarta: Erlangga.

Iswinarti. 2010. Nilai-nilai Terapiutik Permaianan Tradisional Engklek untuk Anak Usia Sekolah Dasar.Malang:Fakultas Psikologi UMM.

Iswinarti. 2005. Identifikasi Permainan Tradisional Indonesia. Laporan hasil survey. Malang: Fakultas Psikologi UMM.

Kemmis Stephen \& McTaggart Robin. 1988. The Action Research Planner. Deakin University Victoria.

Krisdiyatmiko. 1999. Dolanan Anak: Refleksi budaya dan wahana tumbuh kembang anak. Yogyakarta:Plan International Indonesia-Yogyakarta dan LPM Sosiatri Fisipol UGM

Sujiono.,B 2008. Metode Pengembangan Fisik. Jakarta:Universitas Terbuka. 